\begin{tabular}{r|l|l|l}
$\begin{array}{c}\text { Case Reports in } \\
\text { Gastroenterology }\end{array}$ & $\begin{array}{l}\text { Case Rep Gastroenterol 2010;4:404-409 } \\
\text { DOl: 10.1159/000320685 }\end{array}$ & $\begin{array}{l}\text { Published online: } \\
\text { September 28, 2010 }\end{array}$ & $\begin{array}{l}\text { O 2010 S. Karger AG, Basel } \\
\text { ISSN 1662-0631 } \\
\text { www.karger.com/crg }\end{array}$ \\
\hline
\end{tabular}

\title{
Therapeutic Success of Rifaximin for Clostridium difficile Infection Refractory to Metronidazole and Vancomycin
}

\author{
George Tannous Guy Neff Nyingi Kemmer \\ Department of Digestive Diseases, University of Cincinnati College of Medicine, \\ Cincinnati, Ohio, USA
}

\section{Key Words}

Recurrent Clostridium difficile infection - Rifaximin - Vancomycin - Metronidazole · Saccharomyces boulardii

\begin{abstract}
We report the case of a 46-year-old white male with confirmed Clostridium difficile infection for $>4$ weeks after fluoroquinolone therapy. The patient received two courses of metronidazole $500 \mathrm{mg}$ three times daily (t.i.d.) during which time diarrhea resolved; however, symptoms recurred 14-15 days after treatment termination. He received a 2-week course of vancomycin $125 \mathrm{mg}$ four times daily, with symptoms recurring 10 days after treatment conclusion. The patient then received a pulsed tapering schedule of vancomycin with adjunctive Saccharomyces boulardii. Diarrhea recurred 12 days after treatment completion. He received rifaximin $400 \mathrm{mg}$ t.i.d. while hospitalized for diarrhea-associated complications. Symptoms resolved within $24 \mathrm{~h}$. The patient received a 4-week regimen of rifaximin $400 \mathrm{mg}$ orally t.i.d. after discharge. No further episodes of diarrhea were reported within 6 months after treatment termination. The present case supports the potential benefit of rifaximin for the treatment of recurrent Clostridium difficile infection.
\end{abstract}

\section{Introduction}

Clostridium difficile infection (CDI) is a frequent cause of morbidity and mortality among hospitalized patients [1]. This infection typically presents with watery diarrhea without blood in the stool accompanied by lower abdominal pain, fever, and leukocytosis [2]. Symptoms usually occur after antibiotic treatment for previous illness due to the propensity of antibiotics to cause disruption of the gastrointestinal flora, thereby permitting growth of toxigenic $C$. difficile strains [2]. CDI has been increasing in prevalence and severity in recent years, perhaps due to the emergence of uncommon, 


\begin{tabular}{r|l|l|l}
$\begin{array}{c}\text { Case Reports in } \\
\text { Gastruanteriology }\end{array}$ & $\begin{array}{l}\text { Case Rep Gastroenterol 2010;4:404-409 } \\
\text { DOI: 10.1159/000320685 }\end{array}$ & $\begin{array}{l}\text { Published online: } \\
\text { September 28, 2010 }\end{array}$ & $\begin{array}{l}\text { O 2010 S. Karger AG, Basel } \\
\text { ISSN 1662-0631 } \\
\text { www.karger.com/crg }\end{array}$ \\
\hline
\end{tabular}

hypervirulent strains $[1,2]$ and a reduction in efficacy of standard CDI treatments (i.e., metronidazole and vancomycin) $[2,3]$. Indeed, failure rates with first-line therapies of metronidazole and vancomycin are reported to be $22-28 \%$ and $8-19 \%$, respectively [3]. Even after initial resolution of symptoms with standard antibiotic therapy, relapses of CDI occur in approximately $12-24 \%$ of patients [4]. This number increases dramatically (up to 65\%) in patients with multiple instances of CDI recurrence [4]. These data illustrate the need for additional therapeutic options for CDI, especially for patients with multiple recurrences of the disease.

Rifaximin is a nonsystemic, rifamycin-derived antibiotic that has in vitro bactericidal activity against $C$. difficile through inhibition of bacterial RNA synthesis [5]. Rifaximin is currently indicated for the treatment of travelers' diarrhea caused by noninvasive Escherichia coli and the reduction in risk of overt hepatic encephalopathy recurrence [6] and has been shown to elicit no clinically relevant bacterial antibiotic resistance [7]. As rifaximin demonstrates in vitro activity against $C$. difficile [5] and does not significantly alter the gastrointestinal flora [7], rifaximin has been used off label for CDI [5]. An initial study in a hamster model of CDI showed that rifaximin, alone or in combination with vancomycin, increased survival compared with vehicle treatment [8]. In addition, fewer hamsters who received rifaximin therapy $(0 \%)$ had recurrence of CDI compared with animals who received vancomycin $(75 \%, \mathrm{p}<0.01)$ [8]. A subsequent case series of rifaximin use in humans established that rifaximin effectively prevented CDI recurrence when used as a 'chaser' in patients who had symptom resolution induced by vancomycin [9]. Another small, uncontrolled pilot study by Garey et al. [10] demonstrated the efficacy of a tapered regimen of rifaximin in resolving CDI symptoms and preventing disease recurrence. It remains to be seen, however, whether a standard regimen of rifaximin may be effective in resolving CDI. The current case report expounds on the observations of Garey et al. [10] and demonstrates the effective resolution and prevention of recurrence of CDI refractory to standard therapies by rifaximin.

\section{Case Report}

The 46-year-old white male patient experienced symptoms of CDI for $>4$ weeks after completing a fluoroquinolone regimen for an episode of pneumonia. He had multiple previous gastrointestinal problems, including chronic constipation, chronic abdominal pain, and dysphagia. His medical history included coronary artery disease, hypertension, seizures, and bipolar disorder. The patient's surgical history included bilateral splanchnicectomy for chronic pancreatitis, 4-vessel coronary stent placement, and right inguinal hernia repair.

The patient developed CDI after receiving a 2-week course of moxifloxacin $400 \mathrm{mg}$ orally every day for pneumonia and presented with symptoms of bloating, lower abdominal cramping, and $\geq 10$ episodes of watery diarrhea. Stool toxin assay results showed the presence of C. difficile, and flexible sigmoidoscopy indicated the presence of confluent mild colitis with yellow-white pseudomembranes in the sigmoid and descending colon. Subsequent treatment regimens are provided in table 1 . The patient received metronidazole $500 \mathrm{mg}$ orally 3 times daily (t.i.d.) for 2 weeks, and gastrointestinal symptoms abated. Fourteen days after the termination of metronidazole treatment, the patient's abdominal and diarrheal symptoms returned. He again received metronidazole $500 \mathrm{mg}$ t.i.d. for 2 weeks, which resolved the gastrointestinal symptoms, but they returned 14-15 days after treatment termination. After the patient's symptoms returned a second time, he received oral vancomycin $125 \mathrm{mg}$ four times daily (q.i.d.). His symptoms subsided during vancomycin treatment, but 10 days after treatment termination, he called his outpatient gastroenterologist with symptoms of recurrent diarrhea and lower abdominal cramping. He then received a pulsed tapering schedule of vancomycin with adjunctive probiotic therapy of Saccharomyces boulardii $250 \mathrm{mg}$ twice daily. The schedule consisted of vancomycin $125 \mathrm{mg}$ q.i.d. for 1 week, then t.i.d. for 1 week, then every day for 1 week, then every other day for 2 weeks, and then 


\begin{tabular}{r|l|l|l} 
Case Reports in & $\begin{array}{l}\text { Case Rep Gastroenterol 2010;4:404-409 } \\
\text { DOl: 10.1159/000320685 }\end{array}$ & $\begin{array}{l}\text { Published online: } \\
\text { September 28, 2010 }\end{array}$ & $\begin{array}{l}\odot \text { ISSN 1662-0631 } \\
\text { www.karger.com/crg }\end{array}$ \\
\hline
\end{tabular}

every third day for 2 weeks. Diarrheal and abdominal cramping symptoms were alleviated but returned 12 days after the termination of vancomycin treatment. The patient experienced these symptoms for 10 days before he was admitted to the hospital for dehydration and acute renal failure.

On admission, the patient had a white blood cell count of 10,500 cells, which were composed of the following: $76 \%$ neutrophils, $16.8 \%$ lymphocytes, and 5.8\% monocytes. He had elevated hemoglobin and hematocrit values ( $16.2 \mathrm{~g} / \mathrm{dl}$ and $45.5 \%$, respectively), most likely due to low total body water volume. Upon physical examination, the patient appeared dehydrated but had normal levels of blood urea nitrogen $(38 \mathrm{mg} / \mathrm{dl})$ and blood creatinine $(1.4 \mathrm{mg} / \mathrm{dl})$. Stool samples were obtained and tested positive for C. difficile. The patient received intravenous fluid replacement, and his abdominal and diarrheal symptoms were treated with oral rifaximin (XIFAXAN ${ }^{\circledR}$; Salix Pharmaceuticals, Inc., Morrisville, N.C., USA) $400 \mathrm{mg}$ t.i.d. The diarrhea and associated gastrointestinal symptoms resolved within $24 \mathrm{~h}$, and stool samples taken 14 days after rifaximin treatment initiation tested negative for $C$. difficile. The patient was discharged from the hospital and received a 4-week regimen of rifaximin $400 \mathrm{mg}$ t.i.d. No adverse events were reported. During the 6-month follow-up period, he experienced no episodes of diarrhea. Repeat stool samples from 180 days after termination of rifaximin treatment tested negative for $C$. difficile, and flexible sigmoidoscopy revealed absence of pseudomembranes.

\section{Discussion}

The current standard of treatment for initial CDI includes discontinuing the inciting antibiotic and prescribing a regimen of either oral metronidazole or vancomycin [1]; however, recurrence of infection after symptoms have abated completely while on appropriate therapy has been reported [3]. Several studies have described various pharmacotherapeutic regimens to treat recurrent CDI [11-14], but there has not yet been one designated as standard treatment.

Current treatment strategies for recurrent CDI include the use of metronidazole $500 \mathrm{mg}$ t.i.d. for 10 days for initially recurrent cases of CDI [2]. If symptoms recur, pharmacotherapy is usually switched, most often to oral vancomycin $125 \mathrm{mg}$ q.i.d. for 10 days [2]; however, other treatment regimens have been proposed, including treatment with high-dose vancomycin (2 g/day) [13], tapered-dose vancomycin [14], and vancomycin in combination with rifampin (a rifamycin derivative) [15]. Despite the small sample size of these studies $(n=6-22)$, an available treatment algorithm for multirecurrent CDI ( $\geq 3$ episodes) suggests that patients unresponsive to vancomycin $500 \mathrm{mg} /$ day be given a high dose of vancomycin ( $2 \mathrm{~g} /$ day) or have rifampin $600 \mathrm{mg} /$ day added to their current vancomycin regimen [2]. If the diarrheal symptoms continue, colectomy may be advisable [2].

In the case presented, CDI recurred despite several different regimens of metronidazole and vancomycin, including 2 treatments with metronidazole $1,500 \mathrm{mg} / \mathrm{day}$ followed by low-dose vancomycin ( $500 \mathrm{mg} /$ day) and a tapering vancomycin schedule combined with probiotics. Despite this therapy, diarrhea recurred, and the patient developed acute renal failure that required hospitalization for volume and electrolyte repletion. This hospitalization might have been prevented had there been another safe therapeutic option for recurrent CDI after metronidazole and vancomycin treatment. These observations support the necessity of an alternative antibiotic, such as rifaximin (a rifamycin derivative similar to rifampin), for the treatment of recurrent CDI.

Rifaximin is a nonsystemic, gut-selective antibiotic that, unlike rifampin, has an excellent safety profile, with adverse drug interactions and overall adverse events comparable to those associated with placebo [5]. A previous study of 8 patients with 


\begin{tabular}{r|l|l|l}
$\begin{array}{r}\text { Case Reports in } \\
\text { Gastruenterology }\end{array}$ & $\begin{array}{l}\text { Case Rep Gastroenterol 2010;4:404-409 } \\
\text { DOI: 10.1159/000320685 }\end{array}$ & $\begin{array}{l}\text { Published online: } \\
\text { September 28, 2010 }\end{array}$ & $\begin{array}{l}\text { O 2010 S. Karger AG, Basel } \\
\text { ISSN 1662-0631 } \\
\text { www.karger.com/crg }\end{array}$ \\
\hline
\end{tabular}

multiple CDI recurrences who received rifaximin $400-800 \mathrm{mg} /$ day for 2 weeks immediately after vancomycin therapy demonstrated that only 1 of 8 patients (12\%) experienced CDI recurrence [9], suggesting that rifaximin effectively prevents CDI after symptom resolution induced by other antibiotics (i.e., vancomycin). Further, a study by Garey et al. [10] showed that 5 of 6 patients (83\%) had complete resolution of $\mathrm{CDI}$ after receiving rifaximin. These 5 patients received a tapered rifaximin regimen consisting of rifaximin $1,200 \mathrm{mg} /$ day for 14 days followed by rifaximin $600 \mathrm{mg} /$ day for 14 days. Symptom resolution occurred in an average of $8 \pm 5$ days with no recurrence of symptoms during a mean follow-up period of $310 \pm 145$ days. The sixth patient in this study received rifaximin $400 \mathrm{mg}$ t.i.d. for 36 days and had recurrence of C. difficilenegative diarrhea, suggesting that rifaximin was effective for CDI resolution; however, long-term follow-up of this patient was not possible due to the patient's death.

The present case report expounds on the findings of Garey et al. [10] by demonstrating that rifaximin $1,200 \mathrm{mg} /$ day effectively resolved CDI symptoms and achieved bacterial cure in a patient with recurrent CDI refractory to standard therapies. In addition, this case report demonstrates that rifaximin $1,200 \mathrm{mg}$ /day effectively prevented recurrence of CDI for up to 6 months posttreatment. The rapidity of the patient's symptom relief after rifaximin therapy was remarkable, given his history of recurrent diarrhea. The findings from the present case, along with other previously published works $[9,10]$, suggest that rifaximin may offer a promising solution to the frustrating clinical problem of recurrent CDI that faces many clinicians today.

\section{Acknowledgement}

Editorial assistance was provided under the direction of the authors by MedThink Communications with support from Salix Pharmaceuticals, Inc. 
Table 1. Treatment regimens and outcomes for a patient with recurrent CDI

\begin{tabular}{|c|c|c|c|}
\hline Drug & Dose & Duration & Outcome \\
\hline Metronidazole & 500 mg t.i.d. & 2 weeks & $\begin{array}{l}\text { initial resolution of diarrhea followed by } \\
\text { recurrence of symptoms } 14 \text { days posttreatment }\end{array}$ \\
\hline Metronidazole & $500 \mathrm{mg}$ t.i.d. & 2 weeks & $\begin{array}{l}\text { initial resolution of diarrhea followed by } \\
\text { recurrence of symptoms } 14-15 \text { days } \\
\text { posttreatment }\end{array}$ \\
\hline Vancomycin & 125 mg q.i.d. & 2 weeks & $\begin{array}{l}\text { initial resolution of diarrhea followed by } \\
\text { recurrence of symptoms } 10 \text { days posttreatment }\end{array}$ \\
\hline $\begin{array}{l}\text { Tapered vancomycin } \\
\text { with Saccharomyces } \\
\text { boulardii therapy } \\
\text { ( } 250 \text { mg b.i.d.) }\end{array}$ & $\begin{array}{l}125 \text { mg q.i.d. } \\
125 \text { mg t.i.d. } \\
125 \text { mg q.d. } \\
125 \text { mg q.o.d. } \\
125 \text { mg dieb. tert. }\end{array}$ & $\begin{array}{l}1 \text { week } \\
1 \text { week } \\
1 \text { week } \\
2 \text { weeks } \\
2 \text { weeks }\end{array}$ & $\begin{array}{l}\text { initial resolution of diarrhea followed by } \\
\text { recurrence of symptoms } 12 \text { days posttreatment }\end{array}$ \\
\hline Rifaximin & $400 \mathrm{mg}$ t.i.d. & 4 weeks & $\begin{array}{l}\text { initial resolution of diarrhea with sustained } \\
\text { response up to } 6 \text { months posttreatment }\end{array}$ \\
\hline
\end{tabular}

CDI = Clostridium difficile infection; b.i.d. = twice daily; dieb. tert. = every third day; q.d. = every day; q.i.d. $=4$ times daily; q.o.d. = every other day; t.i.d. $=3$ times daily.

\section{References}

1 Calfee DP: Clostridium difficile: a reemerging pathogen. Geriatrics 2008;63:10-21.

2 Owens RC: Clostridium difficile-associated disease: changing epidemiology and implications for management. Drugs 2007;67:487-502.

3 Jodlowski TZ, Oehler R, Kam LW, Melnychuk I: Emerging therapies in the treatment of Clostridium difficileassociated disease. Ann Pharmacother 2006;40:2164-2169.

4 McFarland LV: Alternative treatments for Clostridium difficile disease: what really works? J Med Microbiol 2005;54:101-111.

5 Scarpignato C, Pelosini I: Experimental and clinical pharmacology of rifaximin, a gastrointestinal selective antibiotic. Digestion 2006;73(suppl 1):13-27.

6 Xifaxan [package insert]. Morrisville, NC, Salix Pharmaceuticals, Inc., 2010.

7 DuPont HL, Jiang ZD: Influence of rifaximin treatment on the susceptibility of intestinal Gram-negative flora and enterococci. Clin Microbiol Infect 2004;10:1009-1011.

8 Kokkotou E, Moss AC, Michos A, Espinoza D, Cloud JW, Mustafa N, O’Brien M, Pothoulakis C, Kelly CP: Comparative efficacies of rifaximin and vancomycin for treatment of Clostridium difficile-associated diarrhea and prevention of disease recurrence in hamsters. Antimicrob Agents Chemother 2008;52:1121-1126.

9 Johnson S, Schriever C, Galang M, Kelly CP, Gerding DN: Interruption of recurrent Clostridium difficileassociated diarrhea episodes by serial therapy with vancomycin and rifaximin. Clin Infect Dis 2007;44:846-848.

10 Garey KW, Jiang ZD, Bellard A, DuPont HL: Rifaximin in treatment of recurrent Clostridium difficileassociated diarrhea: an uncontrolled pilot study [letter]. J Clin Gastroenterol 2009;43:91-92.

11 Fekety R, Silva J, Kauffman C, Buggy B, Deery HG: Treatment of antibiotic-associated Clostridium difficile colitis with oral vancomycin: comparison of two dosage regimens. Am J Med 1989;86:15-19.

12 McFarland LV, Elmer GW, Surawicz CM: Breaking the cycle: treatment strategies for 163 cases of recurrent Clostridium difficile disease. Am J Gastroenterol 2002;97:1769-1775.

13 Surawicz CM, McFarland LV, Greenberg RN, Rubin M, Fekety R, Mulligan ME, Garcia RJ, Brandmarker S, Bowen K, Borjal D, Elmer GW: The search for a better treatment for recurrent Clostridium difficile disease: use of high-dose vancomycin combined with Saccharomyces boulardii. Clin Infect Dis 2000;31:1012-1017. 
14 Tedesco FJ, Gordon D, Fortson WC: Approach to patients with multiple relapses of antibiotic-associated pseudomembranous colitis. Am J Gastroenterol 1985;80:867-868.

15 Buggy BP, Fekety R, Silva J Jr: Therapy of relapsing Clostridium difficile-associated diarrhea and colitis with the combination of vancomycin and rifampin. J Clin Gastroenterol 1987;9:155-159. 